\title{
The Ethics of Facing Western Notions in Graham Greene's A Burnt-Out Case
}

\author{
BEATRIZ VALVERDE
}

\begin{abstract}
Taking as a basis Søren Kierkegaard's narrative strategy of attack and defence, this paper will analyse the representation of western civilization in connection with the worldview of the native people living in a leper colony in Belgian Congo in Graham Greene's novel A Burnt-Out Case. I will examine concretely the way in which Greene attacks in the novel the hegemonic structure of the European colonizers, which both ignores and imposes itself on the African native society, considering it a no-structure. Additionally, I will study the cases of the priests in the leper colony and of doctor Colin, characters that, being on the frontier between both value systems, become cultural translators and thus make communication possible. These characters acknowledge that the native way of life is as legitimate as the European and represent the possibility of an empathic side of western civilization. In contrast with the attack mentioned above, with the priests and Dr Colin Greene defends the European community living in the area. Through the use of the narrative strategy of attack and defence, therefore, contradictory messages are inserted in the text so that the readers take an active role solving the paradoxes they find in their reading. Finally, I will focus on the main protagonist, Querry, whose internal journey starts with his contact with Deo Gratias, a member of the native society, and whose spiritual evolution throughout the novel cannot be explained without his experience with the native culture.
\end{abstract}

Keywords: ethics; facing western notions; Graham Greene; A Burnt-Out Case; Søren Kierkegaard; attack and defense

In his review for The New York Times in January, 1962 of Graham Greene's book In Search of a Character: Two African Journals, Charles Poore stated that what the British author did in the way of shedding timely light on the situation in Africa at that time was to show injustice, unrest and the emergence of new African forces. Moreover, he quoted from the book itself: "One feels that European Africa is rapidly disintegrating" (Poore 1962). One of the novels that emerged from Greene's experience in Africa described in the aforementioned journals was A Burnt-Out Case, published in 1960. In it, the writer depicts western civilization in connection with the worldview of the native people in a leper 
colony in Belgian Congo. In this paper, I will analyse the imposing role of the hegemonic structure of the colonizer over the African native society, using Søren Kierkegaard's narrative strategy of "attack and defence." In contrast, I will examine the cases of the priests and doctor Colin, who, being on the frontier between both value systems, become cultural translators and make communication possible. Finally, I will focus on the main protagonist, Querry, whose spiritual journey in the story cannot be explained without his contact with "the other," the native community, represented in this case by Deo Gratias.

In Indøvelse i Christendom (Training in Christianity, 1850), the Danish philosopher Søren Kierkegaard introduces two related dialogic narrative strategies, the method of indirect communication and the method of attack and defence.

Indirect communication can be produced by the art of reduplicating the communication. This art consists in reducing oneself, the communicator, to nobody, something purely objective, and then incessantly composing qualitative opposites into unity. [...] An example of such indirect communication is, so to compose jest and earnest that the composition is a dialectical knot-and with this to be nobody. If anyone is to profit by this sort of communication, he must undo the knot for himself. Another example is to bring defence and attack in such a unity that none can say directly whether one is attacking or defending, so that both the most zealous partisans of the cause and its bitterest enemies can regard one as an ally-and with this to be nobody, an absentee, an objective something, not a personal man. ${ }^{1}$ (1972: 132-133)

Both methods share three main features: first, contradictory messages are inserted in the text, reducing the communicator ${ }^{2}$ to a nobody; second, the role of the readers become active in solving the paradoxes set out in the text; ${ }^{3}$ finally, with both strategies, the readers are made to reconsider their personal

1 For quotations, the translation into English published by Princeton has been used.

2 Communicator here refers to the representation of the implied author. Inserting contradictory ideas, readers cannot get a straightforward idea of the messages conveyed by the implied author when reconstructing this narrative figure. Therefore, as Kierkegaard explains, the communicator is reduced to the minimum expression, giving the reader the responsibility of making sense out of the work.

3 This idea relates Kierkegaard's narrative methods with the theory of reception, mainly with the phenomenological interpretation defended by Wolfgang Iser, in the relevance given to the role of the reader and to the dialectic function of the text, rejecting the idea of it being a simple object (Salvatore 1985: 29). Actually, Roman Ingarden defines the literary work as a series of general guidelines or schemata that the reader needs to actualize (Eagleton 1983: 77). 
view on a certain topic; their conventional assumptions become defamiliarized, objectified, so that they can criticize and revise them. Concretely, the method of attack and defence consists in introducing diverse points of view concerning a certain topic or character, attacking and defending at the same time a given standpoint or worldview. In Kierkegaard's conception, texts, abdicating any kind of authority as moral teachings, are not closed, but open structures with gaps of meaning that the readers need to fill. Therefore, these texts must lead the readers in their hermeneutic role to deal with the ambiguity created and to reconsider, as mentioned before, their own preconceived ideas, opening their minds to new existential possibilities. Graham Greene, influenced by the Danish philosopher, used these same methods in the construction of his work, rejecting the role of moral teacher and converting his novels to "incitements to an awareness of the moral capability or, in Kierkegaardian terms, as inducements to "subjectivity" (Salvatore 1985: 42).

In the dedication of A Burnt-Out Case to doctor Lechat, Graham Greene states: "This Congo is a region of the mind, and the reader will find no place called Luc on any map, nor did its Governor and Bishop exist in any regional capital" (2001). With this statement in mind, we could think that the novel shows the paternalistic attitude of the British writers of the Victorian era in relation to Africa. Moreover, A Burnt-Out Case follows the European pattern, with a protagonist, Querry, who goes through a double journey: a journey to the interior of the African jungle and a journey of self-discovery. These ideas take us to Greeneland, a concept coined in 1940 by Arthur Calder-Marshall in a review for the journal Horizon (McEwan 1988: 17). From that moment on, Greeneland has been widely used by critics in general to refer to the sceneries where the British writer set his stories. Greeneland has been interpreted on many occasions as mere mental recreations that have almost nothing to do with the places that inspired those sceneries (Pearson 1982: 214). ${ }^{4}$ Peter Mudford

4 Greeneland is one of the concepts that are normally associated with Graham Greene and against which the British author fought all his life. In his autobiography, Ways of Escape, he writes about this topic:

Some critics have referred to a strange violent 'seedy' region of the mind [...] which they call Greeneland, and I have sometimes wondered whether they go round the world blinkered. 'This is Indochina,' I want to exclaim, 'this is Mexico, this is Sierra Leone carefully and accurately described. I have been a newspaper correspondent as well as a novelist. I assure you that the dead child lay in the ditch in just that attitude. In the canal of Phat Diem the bodies stuck out of the water...' But I know that argument is useless. They won't believe the world they haven't noticed is like that. (1999: 80) 
asserts that: "[al] though his novels were set in many different countries, his attitudes and his beliefs were, like those of his contemporaries, Eurocentric" (1997: 12). Moreover, David Clark, in his article "Surviving Graham Greene: Why Westerners Face West and Other Western Notions of Interculturality in the Contemporary Novel” insists on Greene's inability to see other cultures through anything but Western eyes, pointing out that:

This is one of the aspects of a legacy that Western literature has to contend with, when it comes to representations of interculturality. To be fair, Western literature is not uniformly colonial, but Greene's position of eminence gives his thinking an undeniable weight. (Clark 2003)

It is difficult to refute these assertions concerning A Burnt-Out Case $e^{5}$ if we consider that the Congo depicted in the novel is "a region of the mind." However, it is necessary to contextualize this idea to really understand what the English writer wanted to express with it. In Ways of Escape, Greene declares that the aim of his visit to the Belgian Congo was to form the background for A BurntOut Case. However, his visit was not productive in this sense, since "the Congo was a geographical term invented by the white colonists" (1999: 37). This view explains why Greene said that the Congo described in the novel cannot be found on any map, ${ }^{6}$ especially if we think that the current map of Africa is the result of

5 This accusation was not only related to the image of the African continent in A BurntOut Case, but to Greeneland in general, to refer to any foreign setting in Greene's work. According to Sheryl Pearson, the British writer just adapted those settings to his narrative purpose (1982: 214). In the case of novels such as The Power and the Glory, there are such categorical comments as the ones by Brian Russel, for whom Greene's México is "a mental entity, a stimulus of the imagination" (1999: 144), or by Manuel Rodríguez, who says that it is a México "de cartón piedra y pasiones calientes" (1995: 88). Contrary to these statements, analyzing comparatively The Power and the Glory and Juan Rulfo's Pedro Páramo (set in Mexico and in the same approximate period), we find so many analogies between both novels that a dissertation could be written on this topic. Concretely, the similarities focus on aspects related to the hegemony of the rich over the disadvantaged, the way the native people are presented in both novels and the role of the Catholic Church in the Mexican society (Valverde 2009).

6 However, the story told in A Burnt-Out Case can be easily set in a concrete period of time. There are several clues throughout the novel that help the readers to do so. First, we are informed that serious riots are taking place in the capital city, Luc (Greene 2001: 12; 14). Later on, the narrator says that the first riots had happened six months earlier (Greene 2001: 43). This information takes us to the demonstrations during the beginning of January, 1959 in Leopoldville to support ABAKO, a pro-independent organization that had had its right of assembly limited by Belgian authorities. Second, we are told 
the white European colonization. For him, Africa was not just the "civilization" created by Europeans with their cities; on the contrary, this creation would not represent the soul of the African continent. The true Africa is the native Africa, which has such an important role in A Burnt-Out Case.

The structure of the society described in the novel is a metaphor of the hegemony of the European civilization over African civilization; through it Greene portrays the effects of the dominant colonialism on the native population, carrying out an attack to the European colonialist system. The society depicted can be divided in two main communities: the westerners and the natives. The relationship established between them is based on the imposition of the former over the latter, with a certain attitude of indifference and disdain on the part of the Europeans towards the native population. The control of the Europeans is carried out at two levels: first, a general level in connection with the historical events of the country's fight for independence that surrounds the story. In addition, the European hegemony is represented by the reduced group of men who control the politics and the economies of the region. We must include in this group the governor, the manager of the trade company Otraco and Rycker, who represents the colonists in the area, all of them with their "respectable" wives. On a second level, this control is noticeable in the interaction between the inhabitants who live near the leper colony, repeating the structure of power described before, with the Europeans as the hegemonic group in the area. It is fundamental to point out, however, that this group is not homogeneous at all. In it, we find those Europeans who keep the status quo of the pretended superiority of the western ideology over the indigenous lifestyle: the colonists and the members of the colonial government. Conversely, we find those who understand that they are dealing with two different but equally valid cultures, being therefore in the frontier between them. This group is formed mainly by most of the priests and Doctor Colin in the leper colony. Their different approach to the native population, compared to the one of the hegemonic group, will have as a consequence the impossibility of any dialectical interaction between these opposing models of community.

that a new Pope has been recently elected (Greene 2001: 14): this fact coincides with the election of Pope John XXIII on October 28, 1958. All this information supports therefore the thesis that the story happens in July, 1959, coinciding with the first months of riots in favor of the independence of Congo from Belgium.

7 This classification is related to Tamas Dobozy's argument, who points out that Greene divides western characters in two groups: the ones that come from an Anglo-Saxon culture, as mixed as any other; on the other hand, those who do not only recognize this fact, but who accept it naturally. With this idea, Dobozy stresses Edward Said's 
Greene's critical reflection on the effects of the colonization in Africa in $A$ Burnt-Out Case focuses first on Dr Colin and Querry's criticism of the European presence on the continent and second on the negative depiction of the European characters who support that hegemonic system and the absurdity of their standpoint. Colin carries out a severe criticism when he refers to the crimes committed by Europeans in different territories in Africa: "Yet in our century you could hardly call them fools. Hola Camp, ${ }^{8}$ Sharpeville, ${ }^{9}$ and Algiers ${ }^{10}$ had justified all possible belief in European cruelty" (Greene 2001: 43). In addition, the exploitation of the continent by the European civilization is shown in the episode of the fake member of the Salvation Army who deceives some natives of one of the tribes so as to get their blankets and their money, taking advantage of their innocence:

As a recompense he had given certificates insuring them against the danger of being kidnapped by the Catholic and Protestant missionaries who, he said, were exporting bodies with the help of witchcraft whole-sale to Europe in sealed railway trucks where they were turned into canned food labelled Best African Tunny. (Greene 2001: 119-120)

Connected to this episode, doctor Colin accuses the European civilization of being the cause of much of the harm done to the population in Africa: "These people here are all dying - oh, I don't mean of leprosy, I mean of us" (Greene 2001: 174). Furthermore, Querry's opinions support such criticism: in his view, what has been built by the Europeans is inappropriate when compared to the natural African setting. In his first visit to Luc, he considers the buildings of European style absurd: "a block of blue and pink modern flats by a little public garden where no one sat on the hot cement benches"11 (Greene 2001: 32).

argument that hybridism is an essential condition in the formation of any culture (2002: 443).

8 A reference to the raising of prisoners in the detention camp of Hola on March $3^{\text {rd }}$, 1959, after the failed rebellion of the Mau Mau against the British colonial government in Kenia. Eleven prisoners were brutally murdered and more than sixty seriously injured.

9 An allusion to the massacre in Sharpeville on March $21^{\text {st }}, 1960$ during a demonstration against the pass laws, one of the dominant features of the country's apartheid system. During the demonstration, police started to shoot indiscriminately at the participants, killing sixty-three of them.

10 Probably a reference to the so-called "Battle of Algiers" during the Argelia's independence war from the French colonial government (1954-1962).

11 Querry's thoughts reflect Greene's opinion on the same topic; about Leopoldville he states: "Brazzaville a far prettier, more sympathetic place than Leo - Europe in Leo 
Finally, in the cathedral: "[...] the European saints, pale like albinos in the dark continent” (Greene 2001: 172).

As mentioned before, the attack on the European imposition on Africa is completed with the characters who alienate themselves from the native culture, such as Rycker and members of the government in the capital, and those who do not make an effort to understand this culture, such as Father Thomas, or reinvent it like the journalist Parkinson. Having lived in this area of the continent for a long time, Rycker and Father Thomas are still deeply rooted in the western norms and forms of life, feeling estranged and living without any connection with the native culture. The journalist, Parkinson, constitutes an extreme case, since not only does he ignore the real Africa, but he also reinvents it for his readers, adapting it to the romantic cliché of the continent that British people still have in mind since Victorian times.

Rycker is the owner of a palm oil factory, which is three days distance by car from the leper colony. His lifestyle spins around the traditional western forms and values, being proud of teaching his wife, Marie, how to be the perfect wife of a colonist: "[...] I've trained her to know what a man needs" (Greene 2001: 36). Rycker maintains the minimum possible contact with the natives, and when he does, he tries to impose western cultural criteria on them, as he shows in the episode at the market, when he says: "You know you have to shout to them a little. They understand nothing else" (Greene 2001: 34). Despite having spent years living in the region, he does not understand the native culture at all. Even the African landscape is depicted in a very different way when the Ryckers are the reflectors in the narrator's discourse. ${ }^{12}$ Both of them consider that the native form of life is inferior, so they are not interested in knowing their symbols, which for them are simply 'things':

Rycker and his wife drove into town for cocktails with the Governor. [...] in the bush thirty kilometres before they had passed something sitting in a chair constructed out of a palm-nut and woven fibres into the rouge and monstruos apperance of a human being. Inexplicable objects were the fingerprints of Africa. (Greene 2001: 61; emphasis added)

From the Ryckers' point of view, the world is divided into civilization (the European way of life) and barbarism (the African forms). Their description

weighs down on the African soil in the form of skyscrapers: here Europe sinks into the greenery and trees of Africa" (Greene 1981: 65).

12 In this sense, as explained before in relation with Kierkegaard's method of attack/ defense, the point of view is essential, given its influence on the readers' conclusions. 
of the native lifestyle seems to be representing a non-human world instead of a different culture. Consequently, they are unaware of the rules regulating this society, as in the episode of the party at the Governor's, with Rycker's complaints about doctor Colin:

That's a man [Colin], you can take it from me, who doesn't know the meaning of the word charity. Do you remember last year when I tried to organize a Lepers' Day? He would have nothing to do with it. He said he couldn't afford to accept charity. Four hundred dresses and suits had been accumulated and he refused to distribute them, just because there weren't enough to go round. He said he would have to buy the rest out of his own pocket to avoid jealousy - why should a leper be jealous? (Greene 2001: 65)

Another relevant character to consider when analysing the attack to the European hegemony is Father Thomas. His ties to the western form of life are shown through his longing for Europe (Greene 2001: 88). As a result, he is unable to adapt to the territory where he lives, even after almost two years of living there (Greene 2001: 86). This fact affects his health, as he cannot sleep well due to his fear of darkness (Greene 2001: 86-87). His narrow-mindedness has also an impact on his ability to communicate with the natives and with the rest of priests in the leper colony. His incapacity leads him to misunderstand the natives when he talks with them:

'I asked Deo Gratias. He said yes. I asked him what prayers - the Ave Maria, I asked him? He said yes'

'Father Thomas, when you have been in Africa a little longer, you will learn not to ask an African a question which may be answered by yes. It is their form of courtesy to agree. It means nothing at all.'

'I think after two years I can tell when an African is lying.' (Greene 2001: 87)

This quotation is even more enlightening when compared with how quickly and easily Querry gets to understand the natives' way of communicating with the white people in the region: "The man [Deo Gratias] said yes, but Querry guessed it was what Africans always replied to a question couched like that" (Greene 2001: 31). Therefore, the problem is not for how long a person has lived in the territory, but how open-minded this person is to a new way of living.

With this character we need to focus as well on the religious sphere introduced in the novel by the British writer. Father Thomas represents the conservative vision of the hierarchy of the Catholic Church before the Second 
Vatican Council, in contrast to the attitude of the rest of the priests in the seminary, who parallel the new spirit of ecumenism and of trying to get closer to the modern world. ${ }^{13}$ In Father Thomas' view, the role of a priest in Africa must focus on preaching the Gospel to the native population, not on the practical tasks of everyday life, in contrast to what the other priests think (Greene 2001: 83). The latter do not even recognize Father Thomas as part of the community, being more at ease in the short period he is absent (Greene 2001: 127). He argues with the Superior of the congregation about moral appropriateness regarding Marie Akimbu's life and her suitability to be the teacher at the school given the fact that she gives birth to a baby each year from different fathers. This conversation is fundamental in understanding how different Father Thomas is when compared with the rest of the priests in the seminary: "What kind of example is that?", asks Father Thomas. The Superior just answers “[...] autres pays autres moeurs" (Greene 2001: 86-87).

The last character who alienates himself from the native culture in the short period he stays in the region is Parkinson. The journalist arrives in Africa with the stereotyped image that his fellow British citizens have of the continent, inherited from the Victorian writers. Determined to keep that image intact, he asks Querry to take some photos getting: “[...] as much atmosphere as you can - you know the kind of thing, black faces gathered round looking worried and sympathetic" (Greene 2001: 99). Parkinson could have been a fundamental character, given the influence that media has on their audience's vision of the world. ${ }^{14} \mathrm{He}$ could have introduced a new text in the minds of his fellow citizens, the one of a true Africa, but his vocation as a research journalist has vanished (Greene 2001: 110). His only motivation is ambition, so he ends up writing: "The eternal forest broods along the banks unchanged since Stanley and his little band" (Greene 2001: 97). Parkinson is aware of the existence of a different Africa, but, whereas Father Thomas and Rycker just ignore it, he uses it instead (Dobozy 2002: 437).

In spite of Greene's fierce attack on the imposition of the European civilization in Africa, the British writer also defends the European community at the same time in the novel, introducing characters who acknowledge that

13 A Burnt-Out Case was published in 1960 and the Second Vatican Council took place between 1962-1965. However, with the priests' lifestyle and their priorities, the novel depicts the changes that were noticeable already since Pope John XXIII was elected in October 1958, convening the Council in January 1959.

14 Parkinson himself reminds Querry of how influential media is in this sense when he warns the architect that he has the power of either praising him to the skies or destroying the image the world has of him (Greene 2001: 167). 
the native way of life is as legitimate as the European. They represent the positive aspects of western civilization, as " $[\mathrm{t}]$ hese characters take Africa as a given, $[\ldots]$ placing service over gain in an attempt to undo or mitigate the harm done in the name of country" (Dobozy 2002: 435). The work of the priests in the leper colony is, as mentioned before, close to the parameters of the Second Vatican Council, which establishes the importance of scrutinizing the signs of the times to interpret them later on in the light of the Gospel (Gadium et Spes, Introductory statement, 4; Bosco 2005: 21). Moral theology, ${ }^{15}$ which is so important for Rycker and Father Thomas, is the least of the fathers' worries. Their daily duty is even more important than preaching the Gospel: "Souls could wait. Souls had eternity" (Greene 2001: 83). The priests accept the way the native culture understands the concept of family and the relationship between men and women; they never try to change these parameters - despite not being in accordance with the Vatican's official moral theology - baptizing all children even if they have been born out of wedlock (Greene 2001: 120).

In addition, the attitude of these priests is totally ecumenical. They work elbow to elbow with doctor Colin, even though as Colin himself states " $\mathrm{t}]$ here are many priests who wouldn't be happy to work with an atheist for a colleague" (Greene 2001: 82). Most importantly, they do not pretend that Africans will practice Catholicism as it is conceived in Europe, accepting the way the natives interpret it, characterized by syncretism between Jesus and Nzambe, and considering them members of the Christian community. Doctor Colin defines it: "It's a strange Christianity we have here" (Greene 2001: 58). The homily of the Superior is particularly relevant. The sermon is adapted to the audience for whom it is intended. The Superior speaks the way the natives do, syntactically and even phonetically, using as well words coming from their native language:

'Now I tell you that when a man loves, he must be Klistian. When a man is merciful he must be Klistian. In this village do you think you are the only Klistians - you who come to church? There is a doctor who lives near the well beyond Marie Akimbu's house and he prays to Nzambe and he makes bad medicine. He worships a false God, but once when a piccin was ill and his father and other were in the hospital he took no money; he gave bad medicine but he took no money [...] I tell you then he was a Klistian, a better Klistian than the man

15 Greene always felt unease regarding moral theology. In different novels we find strong statements, such as the one about Father Jean's past in A Burnt-Out Case: "He has once been a brilliant moral theologian before he joined the Order and now he carefully nurtured the character of a film-fan, as though it would help him to wipe out an ugly past" (2001: 83). 
who broke Henry Okapa's bicycle. He did not believe in Yezu, but he a Klistian. [...] Everybody in the world has something that Yezu made. Everybody in the world is that much a Klistian (Greene 2001: 80-1).

According to Woodman, in this sermon " $[\mathrm{t}]$ here seems to be a clear suggestion here of Rhaner's concept of anonymous Christians, and there is no doubt that Greene himself finds the idea sympathetic and even consoling” (2002: 144-5; emphasis in the original). The conveyed message is that the limits of what is considered to be a Christian must be deconstructed and outlined again, going back to the original concept of Christianism. ${ }^{16}$

The defence of the presence of the European civilization in the territory includes the character of doctor Colin. Like the priests in the seminary, Colin accepts the native culture the way it is. As an example, Colin has learnt to accept that Africans can foresee exactly the day they will pass away (Greene 2001: 48). Yet, his aim in life is to eradicate leprosy (Greene 2001: 22). He tries to bring the European technological advances to Africa so as to prevent the onset of this disease, such as the Atlas of Leprosy (Greene 2001: 20) or a new X-ray machine (Greene 2001: 94). Moreover, he wants to get orthopedic devices that would make the life of the mutilated lepers easier (Greene 2001: 79). His standpoint is, however, totally western, since he does not think about asking the natives whether or not they would like to use such devices: "For Dr. Colin, the best man can hope to do is improve his little corner of the world or try to provide instruments that will do it for us." (Hill 1999: 77) In addition, in Colin we do not find personal commitment since he pays more attention to the symptoms of leprosy than to his patients' suffering. As a result, he does not connect with them at a personal level. In an interview, Greene comments on the doctor's paradoxical attitude compared with the practical mindset of the priests:

In A Burnt-Out Case, for example, Dr Colin is an atheist, but he ponders on the origins of human kind, while the priests with whom he rubs shoulders seem less mystical than he, preoccupied as they are with building shelters for the lepers or raising money for their hospital. It's all a paradox and that's what interests me. (Allain 1983:19)

16 Pérez Aguirre explains that the term Catholicism comes from the ancient Greek kataholon, meaning "according to all aspects," that is, what is conciliatory, not exclusive. Actually, the message of Jesus in the Gospel is to include the ones who have been excluded (Pérez 1979: 27). 
For this reason, the character of the doctor is part of the defence of the European civilization carried out in the novel, but only partially when compared with the priests, who can establish a bond of love with their fellow man.

Together with this attack/defence of the presence of the European civilization on the continent and the generated ambiguity that the readers need to solve, Greene highlights the relevance of the contact with 'the other', the native culture, mainly through the character of Querry. Africa, illustrated by the leper colony, means a turning point in the life of the famous architect (Smith 1987: 161). His spiritual evolution, from being a 'passenger' without roots (Greene 2001: 19-20) to a man that fights to keep the new life he has managed to build (Greene 2001: 135), would have not been possible if he had not come to this region and had not been in touch with the authenticity that characterizes the native culture. Actually, it is by leaving behind a paternalist standpoint towards the natives (Greene 2001: 58) that the famous architect glimpses the possibility of a new beginning in his life. A Burnt-Out Case emphasizes the criticism of colonialism through Querry's overcoming of his faith crisis. Therefore, Africa plays an important role from the spiritual point of view (Dobozy 2001: 455). Actually, Querry's struggle “involves an attempt to reject the Victorian encounter with Africa in its political, religious, and literary forms [...] Through Querry, then, Greene revisits and rewrites the history of the Victorian encounter with Africa." (Nordlof 2002: 473) Querry, together with the priests and doctor Colin, bring together the European and the native cultures and make possible the contact between them, becoming cultural translators, in contrast with those characters who simply ignore or even despise the culture of 'the other'.

To conclude, the encounter with 'the other' and the relationship that the different characters build with the new culture become extremely relevant in the novel. ${ }^{17}$ In addition, bearing in mind the attack carried out to the European imposing attitude of some of the characters, the critics' frequent references to Greeneland and their accusations of Eurocentrism when analysing the novel become questionable. Contrary to them, my conclusion is that A Burnt-Out Case was written as an effort to distance itself from the traditional paternalistic

17 According to Paula Martín, "Greenean ethics is, as Derrida would say, following a Lévinassian approach, an ethics of the other. [...] In this sense, Greene's work may be said to explore the potential constitution of forms of community based on ethical action, established as alternative - often opposed - to official or institutional communities" (2015: 7). 
VALVERDE

treatment of Africa ${ }^{18}$ by denouncing the negative consequences of colonization in the continent and by emphasizing at the same time the authentic, native Africa, praising cultural diversity and understanding, concepts promoted by those who, with an open-minded attitude, are willing to accept and to learn from 'the other'.

\author{
Beatriz Valverde Jiménez \\ bvalverde@uloyola.es \\ Communication and Education \\ Faculty of Social Sciences and Humanities \\ Universidad Loyola Andalucía \\ C/ Energía Solar, 1 \\ 41014 Sevilla \\ ESPAÑA / SPAIN
}

\title{
Bibliography
}

Allain, M.-F. 1983. The Other Man: Conversations with Graham Greene. London: Bodley Head.

Bosco, M. 2005. Graham Greene's Catholic Imagination. New York: Oxford University Press.

Clark, D. 2003. Surviving Graham Greene: Why Westerners Face West and Other Western Notions of Interculturality in the Contemporary Novel. - InternetZeitschrift für Kulturwissenschaften, 15, http://www.inst.at/trans/15Nr/02_8/ clark15.htm (18.11.2016).

Dobozy, T. 2002. Africa and Catholic Crisis: Graham Greene's The Heart of the Matter and A Burnt-out Case. - T. Hill, ed., Perceptions of Religious Faith in the Work of Graham Greene. New York: Peter Lang, 427-458.

Eagleton, T. 1983. Literary Theory: An Introduction. Oxford: Blackwell.

Gadium et spes.

http://www.vatican.va/archive/hist_councils/ii_vatican_council/documents/ vat-ii_const_19651207_gaudium-et-spes_en.html (18.11.2016)

Greene, G. 1981. In Search of a Character. London: Penguin.

Greene, G. 1999. Ways of Escape. London: Vintage.

Greene, G. 2001. A Burnt-Out Case. London: Penguin Books.

Hill, T. 1992. Graham Greene's Wanderers. San Francisco: International Scholars Publications.

18 As Dobozy points out, "Unlike Conrad, Greene [...] retains the burden of guilt for the effects of colonialism upon the West. In Conrad, Western civilization succumbs to the heart (i.e. essential) darkness; in Greene Western Civilization succumbs to itself" (2002: 432). 
The Ethics of Facing Western Notions in Graham Greene's A Burnt-Out Case

Kierkegaard, S. 1972. Training in Christianity. NJ: Princeton University Press.

Martín, P. 2015. The Language of Ethics and Community in Graham Greene's fiction. Basingstoke: MacMillan Palgrave.

McEwan, N. 1988. Graham Greene. London: MacMillan.

Mudford, P.1996. Graham Greene. Plymouth: Northcode House.

Nordlof, J. 2002. Faith and Disloyalty in Greene's African Fiction. - T. Hill, ed., Perceptions of Religious Faith in the Work of Graham Greene. New York: Peter Lang, 459-478.

Pearson, S. 1982. “Is There Anybody There?” Graham Greene in Mexico. - Journal of Modern Literature. 9, 2, 277-290.

Pérez, D. 1979. El factor humano. - Insula. 391, 7.

Poore, C. 1962. Books of the Times. The New York Times, https://www.nytimes.com/ books/00/02/20/specials/greene-search2.html (18.11.2016).

Rodríguez, M. 1995. El México de Juan Rulfo. - Cuadernos cervantinos de la lengua española, 2, 88-93.

Russel, B. 1999. Mexicos of the Mind: British Writers of the 1930s in Mexico. Michigan: UMI.

Salvatore, A. 1985. Graham Greene, Søren Kierkegaard, and the Discourse of Belief. Michigan: UMI.

Smith, G. 1987. A Burnt-Out Case. - H. Bloom, ed., Graham Greene. Philadelphia: Chelsea House Publihsing, 153-164.

Valverde, B. 2009. El padre Rentería y el pater whisky cara a cara: Catolicismo y sociedad en México en Pedro Páramo de Juan Rulfo y The Power and the Glory de Graham Greene. - Alcalá de Henares: XXI Congreso de ALDEEU, June 29, 2009.

Woodman, T. 2002. Graham Greene and the Paradoxical Church of The Power and the Glory. - T. Hill, ed., Perceptions of Religious Faith in the Work of Graham Greene. New York: Peter Lang, 619-656. 